Vol. 1 | No. 3 | Juli 2020 | Hal. 193 - 199

\title{
PEMBERDAYAAN MASYARAKAT DESA DALAM PEMBUATAN TAMAN SEBAGAI MEDIA PENGEMBANGAN DESA WISATA
}

\author{
Bagus Cahyanto1, Siti Asfirotul Khasanah', Nuril Khausumah1, Siti Nur Rukhoyah', \\ Miftahunnikmah', Muhamad Irfan Diky Kurniyanto ${ }^{2}$, Reza Dewa Brata ${ }^{3}$, Kapsir ${ }^{2}$, \\ Dinar Supraba Taranggana $\mathrm{Aji}^{3}$, Harianto ${ }^{4}$, Seto Dhutomangkoro Sabdogati ${ }^{2}$ \\ ${ }^{1}$ Fakultas Agama Islam, Universitas Islam Malang \\ ${ }^{2}$ Fakultas Ekonomi dan Bisnis, Universitas Islam Malang \\ ${ }^{3}$ Fakultas Teknik, Universitas Islam Malang \\ ${ }^{4}$ Fakultas Keguruan dan Ilmu Pendidikan, Universitas Islam Malang
}

Korespondensi email: baguscahyanto@unisma.ac.id

\begin{abstract}
ABSTRAK
Sumber daya manusia merupakan salah satu faktor penting dalam berbagai bidang, termasuk dalam hal pengelolaan dan pengembangan obyek wisata. Peningkatan sumber daya manusia yang ada didaerah kawasan wisata dapat meningkatkan kemampuan dalam pengelolaan dan pengembangan potensi yang ada didaerah tersebut. Peningkatan sumber daya manusia dapat dilakukan melalui berbagai kegiatan dan program. Oleh karena itu melalui program pengabdian kepada masyarakat ini, melakukan pelatihan dan dan pendampingan kepada dua kelompok yaitu karang tarunan dan PKK. Tujuan kegiatan ini yaitu untuk meningkatkan kualitas SDM desa Jogomulyan. Hasil kegiatan peningkatan sumber daya manusia dilakukan melalui pelatihan dan pendampingan kepada dua kelompok karang tarunan dan PKK dengan fokus dan pokok materi tentang: desa wisata. Kegiatan ini mendapat sambutan yang sangat yang baik, dapat dilihat dari antusiasme dan keaktifan peserta. Selain itu keberhasilan kegiatan ini dapat di lihat dari produk taman yang dihasilkan oleh peserta dengan cukup indah dan siap dikunjungi oleh wisatawan.
\end{abstract}

Kata Kunci: workshop; pelatihan; pendampingan; desa wisata.

\section{PENDAHULUAN}

Jogomulyan adalah desa yang terletak di kecamatan Tirtyoyudo, desa Jogomulan ini memiliki lahan pertanian kopi dan salah yang sangat luas. Desa Jogomulyan mempunyai potensi sebagai desa wisata, namun masyarakatnya belum paham tentang pengembangan desa wisata. Dari hasil observasi menunjukkan bahwa banyak fasilitas belum terdeteksi, baik dari fasilitas umum seperti infrastruktur atau identitas desa, penunjuk jalan dan spot foto yang menarik untuk dikatakan sebagai desa wisata.

Mayarakat lokal, terutama penduduk asli yang bermukim di kawasan wisata, menjadi salah satu pemain kunci dalam pariwisata, karena sesungguhnya merekalah yang akan menyediakan sebagian besar atraksi sekaligus menentukan kualitas produk wisata (Andini, 2013; Hermawan et al., 2017). Masyarakat lokal merupakan pemilik langsung atraksi wisata yang di kunjungi sekaligus di konsumsi oleh wisatawan. Aktifitas masyarakat lokal seperti mengelola lahan pertanian tradisional (Raharjana, 2012; Insani et al., 2019). Tidak jarang masyarakat lokal lebih dahulu terlibat dalam pengelolaan aktivitas pariwisata sebelum ada kegiatan pengembangan dan perencanaan. Terbukti dari adanya 
pengolahan hasil pertanian yaitu keripik salah dan nangka. Oleh sebab itu peran masyarakat lokal tidak bisa dihilangkan dalam penyediaan tenaga kerja dalam industri wisata (Aryunda, 2011).

Perlunya kegiatan pendampingan masyarakat untuk dapat membangun kesadaran tentang potensi wisata yang dimiliki wilayah Kecamatan Tirtoyudo, khususnya Desa Jogomulyan. Pendampingan masyarakat ini dapat di mulai dari kelompok masyarakat seperti tim penggerak PKK, dan Karang Taruna desa dalam meningkatkan Kapasitas Sumber Daya Manusia (SDM) kepariwisataan khususnya dalam meningkatkan kesadaran dan kepekaan masyarakat lokal. Pendampingan ini juga diharapkan dapat memberikan pengetahuan dasar kepariwisataan kepada lembaga pendidikan, pelatihan, dan industri dalam pengembangan wisata. Selain itu juga menciptakan kader-kader pariwisata untuk berpatisipasi aktif dalam mengembangkan wisata (Ayu, 2020).

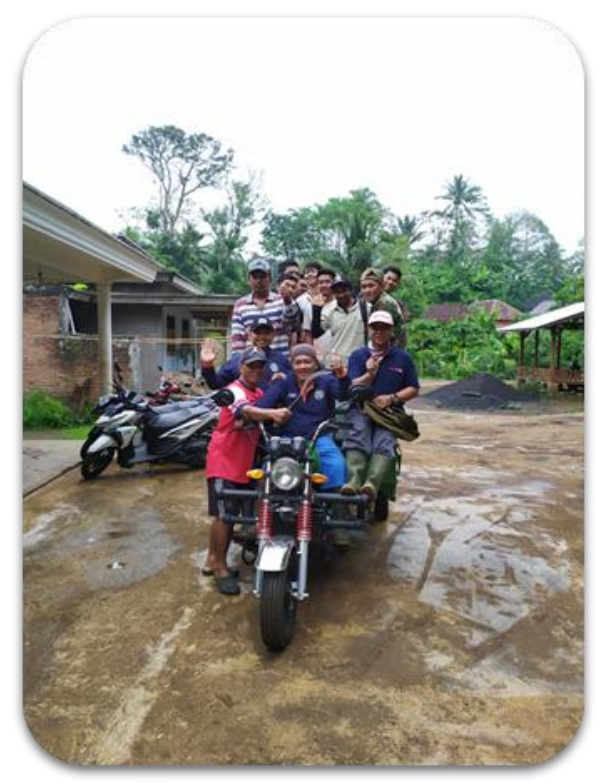

Gambar 1. Pembuatan taman bersama warga

Desa wisata adalah suatu wilayah pedesaan yang menawarkan keaslian baik dari segi sosial budaya, adat-istiadat, keseharian, arsitektur tradisional, struktur tata ruang desa yang disajikan dalam suatu suatu bentuk integrasi komponen pariwisata antara lain seperti atraksi, akomodasi dan fasilitas pendukung (Zakaria \& Suprihardjo, 2014; Hilman, 2016).

Komponen-komponen wisata akan saling terkait dalam pendukung pengembangan suatu kawasan. Komponen wisata dibagi atas dua faktor, yaitu komponen penawaran (supply) dari wisata dan komponen permintaan (demand) dari wisata. Sediaan wisata mencakup segala sesuatu yang ditawarkan kepada wisatawan meliputi atraski wisata, akomodasi, transportasi, infrastruktur, fasilitas pendukung. Sedangkan permintaan atau demand wisata adalah segala sesuatu yang berhubung dalam permintaan wisata yaitu pengunjung dan masyarakat (Suprapto, 2005; Siboy, 2020).

Menurut Suwantoro (2004) komponen desa wisata (a). Keunikan, keaslian, sifat khas (b). Letaknya berdekatan dengan daerah alam yang luar biasa (c). Berkaitan dengan kelompok atau masyarakat berbudaya yang secara hakiki menarik minat pengunjung. (d) Memiliki peluang untuk berkembang baik dari sisi prasarana dasar, maupun sarana lainnya. Sedangkan Menurut Atmoko (2014) komponen desa wisata (a) Memiliki potensi pariwisata, seni, dan budaya khas daerah setempat. (b) Lokasi desa masuk dalam lingkup 
daerah pengembangan pariwisata atau setidaknya berada dalam koridor dan rute paket perjalanan wisata yang sudah dijual. (c) Diutamakan telah tersedia tenaga pengelola, pelatih, dan pelaku-pelaku pariwisata, seni dan budaya. (d) Aksesibilitas dan infrastruktur mendukung program Desa Wisata. (e). Terjaminnya keamanan, ketertiban, dan kebersihan.

Proses pemberdayaan masyarakat melalui pengembangan desa wisata di desa jogomulyan melalui tiga tahapan meliputi tahap penyadaran, tahap kapasitasan dan tahap terakhir tahap pemberian daya. Tahap pertama adalah tahap penyadaran dimana pada tahap ini dilakukan workhsop pembentukan desa wisata kepada warga masyarakat desa. Proses workhsop dilakukan oleh para mahasiswa KKN dengan memberikan pemahaman kepada masyarakat tentang pembentukan desa wisata dilingkungan tempat tinggal mereka. Proses ini sejak awal tidak menemukan kendala yang berarti karena sebelumnya belum berstatus sebagai desa wisata.

Desa wisata Jogomulyan telah lama dikenal memiliki potensi wisata alam, seiring perkembangan waktu para masyarakat di desa Jogomulyan berusaha untuk mengembangkan potensi wisata lain, yang dikembangkan dari kehidupan warga seharihari. Di desa Jogomulyan sendiri tidak hanya ada wisata alam, tetapi juga ada wisata petik kopi, petik salak, dimana kita bisa ikut para petani mulai dari memetik kopi sampai meroasting kopi hingga kita meminum kopi. Untuk salak sendiri kita bisa juga memetik langsung dari pohonnya sampai kita turut membantu proses pembuatan keripik salak. Pembangunan desa wisata tidak lepas dari peran serta seluruh masyarakat.

Pendampingan masyarakat memang perlu dan penting. Tugas utama seorang pendamping adalah memfasilitasi proses belajar atau refleksi dan menjadi mediator untuk masyarakat. Pendampingan merupakan kegiatan yang diyakini mampu mendorong terjadinya pemberdayaan fakir miskin secara optimal. Perlunya pendampingan dilatarbelakangi oleh adanya kesenjangan pemahaman di antara pihak yang memberikan bantuan dengan sasaran penerima bantuan. Kesenjangan dapat disebabkan oleh berbagai perbedaan dan keterbatasan kondisi sosial, budaya, dan ekonomi. Oleh karenanya para pendamping di tingkat lokal harus dipersiapkan dengan baik agar memiliki kemampuan untuk memfasilitasi dengan sumber-sumber baik.

\section{METODE}

Metode kegiatan pelatihan dan pendampingan dilaksanakan dalam bentuk pelatihan, workshop, dan pendampingan. Kegiatan pada masing-masing kelompok melibatkan warga karang taruna dan ibu-ibu PKK.

\section{Workshop Pengembangan Desa Wisata Jogomulyan}

Melalui workshop ini, kelompok diharapkan mampu merancang layanan di desa Jogomulyan. Dengan demikian kelompok mampu melayani berbagai special interest pengguna desa wisata Jogomulyan. Penambahan taman/assembly point akan memberikan dampak ekonomis. Namun tetap harus mempertimbangkan daya dukung ekosistem. Kegiatan Workshop ini yaitu pengembangan desa wisata, mulai dari apa yang dimaksud desa wisata, komponen apa saja yang ada di desa wisata. Dan apa saja penunjang desa wisata. Workshop ini diikuti seluruh anggota karang taruna yang berjumlah 72 orang yang dilaksanakan setiap hari minggu jam 6 pagi sampai jam 10 pagi. Kegiatan ini dilaksanakan setelah kelompok dan anggota karang taruna melakukan kerja bakti didaerah coban yang akan dibangun.

\section{Pelatihan Desa Wisata Jogomulyan}

Melalui pendampingan ini, diharapkan hasil pelatihan dapat di tindaklanjuti dan dapat dilakukan pengembangan berdasarkan pengalaman yang muncul selama pelatihan. Pengembangan ini dilakukan sebanyak 20 orang anggota karang taruna, dan dilakukan 
sebanyak 3 kali. Selain kegiatan tersebut, para pemuda juga dibekali pengelolaan obyek wisata dan apa saja komponen desa wisata. Kunjungan dilaksanakan pada 14 Februari 2020. Kegiatan kunjungan belajar dilaksanakan didua tempat, yaitu coban yang akan dibangun sehingga menghasilkan ide yang untuk membangun taman assembly point sebagai hasil atau produk dari pelatihan.

\section{Pendampingan}

Peran pendamping di Desa Wisata Jogomulyan pada awalnya adalah sebagai motivator dan penggagas ide, yaitu berupaya untuk menyadarkan dan mendorong masyarakat untuk mengenali potensi dan masalah yang ada. Dari mengembangkan potensi tersebut kemudian akan memecahkan permasalahan yang ada. Selanjutnya pada tahap pelaksanan. Menurut Safni (2015) peran pendamping berusaha memberikan pengarahan dan pelatihan komponen dan faktor penunjuang desa wisata, pengelolaan obyek wisata coban, dan manajemen pengelolaan wisata perdesaan. Pada tahap ini, pendamping mempunyai tanggung jawab untuk menciptakan, mengkondisikan iklim kelompok yang harmonis, serta memfasilitasi terjadinya proses saling kerja sama dalam kelompok. Dalam hal ini dilakukan pendampingan intensif hingga ide-gagasan atau produk benar-benar selesai.

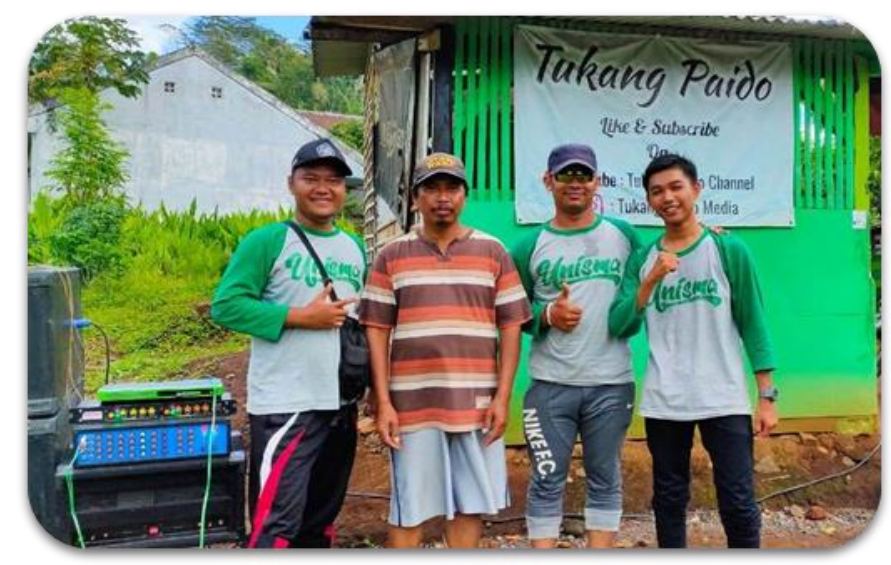

Gambar 2. Kegiatan pelatihan dan pendampingan

\section{Alat}

Alat yang digunakan dalam kegiatan workhsop yaitu, mic, dan shound, LCD dan proyektor. dalam kegiatan pendampingan alat yang digunakan yaitu, cangkul, sabit, sapu, cikrak, air, pot bunga dll.

\section{Evaluasi}

Dalam melakukan kegiatan worhshop, pelatihan, dan pendampingan terdapat banyak kendala seperti: hujan, dan jarak yang jauh dari rumah-rumah warga yang ada. Seperti dusun kampung pete, dan dusun tretes sehingga workhsop, pelatihan, dan pendampingan di lakukan di berbagai tempat. Misalnya di dusun 1 digabung sampai dusun 2,3,4, dan 5 . Sehingga warga yang rumahnya jauh bisa mengikuti workhsop, pelatihan, dan pendampingan dirumah warga yang di sepakati seperti rumah pak joko, pak sunyoto, dan pak lami.

\section{HASIL DAN PEMBAHASAN}

Workshop dilakukan dilakukan mulai tgl 5 februari, selanjutnya dilakukan pada hari minggu tgl 9 febuari 2020 dengan jumlah 72 peserta dan lokasinya bertempat di kantor desa Jogomulyan dengan materi desa wisata (komponen desa wisata, pendukung desa wisata). Dalam proses pelaksanaan sosialisasi workshop juga mendapat masukan 
dari aparat desa dan kepala desa bahwa Jogomulyan ini sedang dalam progres membangun wisata air terjun yaitu coban Jogomulyan. Masukan dari kepala desa mengharapkan mahasiswa KKN menyumbangkan ide dalam pengelolaan dan penataan dalam akses jalan menuju coban. Adanya ide sehingga potensi coban di Jogomulyan lebih dikenal atau dapat diminati oleh masyarakt sehingga dapat tertarik untuk berkunjung ke Jogomulyan. Berdasarkan masukan dari kepala desa tersebut sehingga tim pengabdi bersama peserta workshop muncul ide yaitu membuata taman yang dilengkapi spot foto sebagai daya pendukung untuk menarik pengunjung yang akan berwisata ke coban. Setelah ide ini di setujui oleh kepala desa, tim pengabdi dan masyarakat mendesain taman.

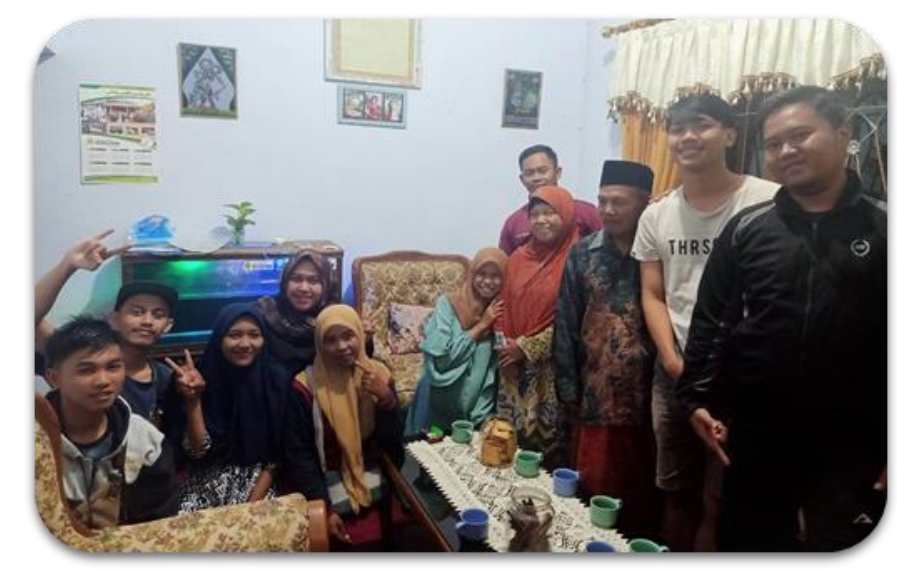

Gambar 3. Pendampingan bersama warga

Indikator yang ingin dicapai oleh pengabdi sudah mencapai tahap 90\%. Yaitu tahap workshop pelatihan dan pendampingan. Dengan penjelasan dalam tahap sosialisasi atau workshop diikuti oleh seluruh anggota karang taruna yang berjumlah 72 orang yang dilaksanakan setiap hari minggu jam 6 pagi sampai jam 10 pagi. Kegiatan ini dilaksanakan setelah kelompok dan anggota karang taruna melakukan kerja bakti didaerah coban yang akan dibangun. Selanjutnya keberhasilan dari workshop dapat membuat peserta tertarik untuk mengikuti kegiatan selanjutnya yaitu pelatihan desa wisata hingga mendapat masukan dari kepala desa sampai muncul ide untuk membuat produk taman sebagai daya dukung dari wisata coban. Yang dilanjutkan dengan kegiatan pendampingan dalam desain - progres untuk membangun taman. Pendampingan ini dilakkukan secara intensif di mulai dari 15 februari 2020 sampai produk taman telah selesai dan siap untuk di singgahi.

Pelaksanaan kegiatan pendampingan pembuatan taman terdiri dari beberapa tahap, yaitu sebagai berikut:

\section{Tahap persiapan membuat taman}

Pada tahap ini tim pelaksana menentukan tema atau konsep yang akan dibuat. Konsep dibuat sesuai dengan kondisi lingkungan dan tujuan dibangun taman yaitu sebagai fasilitas pendukung wisata coban. Tahap berikutnya yaitu membersihkan lokasi hal ini dilakukan agar mempermudah penataan dan penanaman. Setelah semua bersih dilakukan pemilihan bunga yang akan ditanam dan desain dari taman itu sendiri.

\section{Tahap penataan dan penanaman}

Pada tahap ini dilakukan penataan tempat bunga yang akan di tanam dan penataan meja dan kursi sekaligus penataan bunga identik atau bunga gantung.

3. Tahap perawatan dan papan nama sekaligus edukasi bagi calon wisatawan Pembuatan taman ini nantinya dapat dikembangkan pada lokasi lainnya sebagai daya dukung wisata coban. Pendampingan yang dihasilkan pada kegiatan pengabdian 
masyarakat ini terlihat sedikit banyak memprbaikai kualitas visual desa Jogomulyan. Umpan balik peserta dilakukan sebagai evaluasi pelaksanaan kegiatan pengabdian masyarakatan. Peserta dimintai wawancara pada akhir kegiatan. Wawancara dilakukan kepada ketua karang taruna dan kepala desa. Hasil wawancara menunjukkan bahwa belum pernah ada pelatihan sekaligus pendampingan semacam ini sehingga peserta tertarik mengikuti kegiatan ini. Sebagian besar peserta menilai positif kegiatan ini dan berharap pendampingan ini dapat memberikan banyak sumbangsih pengembangan SDM agar dapat mengembangkan potensi wilayah desa.

Sehingga dalam kegiatan tersebut dapat meningkatkan sumber daya masyarakat desa jogomulyan, karena para mahasiswa berhasil mengubah mindset warga desa jogomulyan yang semula desa tersebut memiliki potensi wisata tapi tidak dikembangkan, kemudian dengan adanya mahasiswa KKN UNISMA 2020 ini, sumber daya manusia di desa jogomulyan dapat meningkat, karna mahasiswa KKN tahu bahwa desa jogomulyan memiliki potensi wisata yang bagus, tetapi kurang dalam pengembangan, untuk itu para mahasiswa KKN mengadakan workhsop, pelatihan, serta pendampingan yang diberikan oleh mahasiswa KKN UNISMA 2020. Sehingga dengan adanya workhsop, pelatihan serta pendampingan, masyarakat desa jogomulyan menyetujui di adakanya pembuatan taman akses jalan menuju coban/ air terjun. Yang dimana air terjun tersebut nantinya akan menjadi wisata yang ada di desa jogomulyan, dengan ditambah kebun salak dan kebun kopi. Adapun kendala yang di dapat dari workhsop, pelatihan dan pendampingan ini yaitu, munculnya doktrin bahwa yang membangun desa/ mengembangkan desa wisata adalah aparat desa bukan masyarakat sulitnya adalah menyakinkan masyarakat bahwa masyarakat juga merupakan bagian dari suksesnya pembagunan desa wisata.

\section{KESIMPULAN}

Pengabdian masyarakat berupa workshop, pelatihan dan pendampingan ini terlaksana dengan baik dan sangat sesuai dengan indikator. Output dari pengabdian ini adalah meningkatnya sumber daya masyarakat jogomulyan terkait desa wisata yang dimiliki desa jogomulyan. Sehingga menghasilkan produk berupa taman yang bisa menjadi daya dukung wisata di desa jogomulyan, sehingga bisa mendarik masyarakat luas untuk datang ke desa jogomulyan dan juga bisa memperbaiki pemandangan/ keindahan yang ada di desa jogomulyan.

\section{DAFTAR RUJUKAN}

Andini, N. (2013). Pengorganisasian Komunitas dalam Pengembangan Agrowisata di Desa Wisata, Studi Kasus: Desa Wisata Kembangarum, Kabupaten Sleman. Journal of Regional and City Planning, 24(3), 173-188. https://doi.org/10.5614/jpwk.2013.24.3.2

Aryunda, H. (2011). Dampak Ekonomi Pengembangan Kawasan Ekowisata Kepulauan Seribu. Journal of Regional and City Planning, 22(1), 1-16. https://doi.org/10.5614/jpwk.2011.22.1.1

Atmoko, T. P. H. (2014). Strategi Pengembangan Potensi Desa Wisata Brajan Kabupaten Sleman. Jurnal Media Wisata, 12(2), 146-154. https://doi.org/10.36276/mws.v12i2.87

Ayu, I. K. (2020). Mengembangkan Potensi Desa Bringin Menjadi Desa Wisata. Jurnal Pembelajaran Pemberdayaan Masyarakat (JP2M), 1(1), 1-5. https://doi.org/10.33474/jp2m.v1i1.4992

Hermawan, H., Brahmanto, E., Hamzah, F., Ghani, Y., Somantri, P. R., Priyanto, R., ... Suryana. 
(2017). Panduan Wisata Edukasi (1st ed.). Bandung: Program Pengabdian Masyarakat STP ARS Internasional Bandung. https://doi.org/10.31219/osf.io/6qspg

Hilman, Y. A. (2016). Kajian Kritis Tentang Inovasi Daerah Terkait Pengembangan dan Pengelolaan Desa Wisata Berbasis Komunitas. Jurnal Ilmiah Pariwisata (JIP), 21(1), $1-9$.

Insani, N., A'Rachman, F. R., Ningsih, H. K., \& Rachmawati, A. P. (2019). Pendampingan Masyarakat Dalam Peningkatan Kapasitas Sumber Daya Manusia (SDM) Kepariwisataan Kabupaten Sidoarjo. Jurnal Praksis Dan Dedikasi Sosial, 2(1), 28-35. https://doi.org/10.17977/um032v0i0p28-35

Raharjana, D. T. (2012). Membangun Pariwisata Bersama Rakyat: Kajian Partisipasi Lokal Dalam Membangun Desa Wisata Di Dieng Plateau. Jurnal Kawistara, 2(3), 225-237. https://doi.org/10.22146/kawistara.3935

Safni, I. (2015). Konsep Penguatan Peran Stewardship (Analisis Peran Pendampingan dalam Memberdayakan Masyarakat di Kelurahan Guntung melalui Program Kegiatan CSR PT Pupuk Kaltim). Jurnal Kinerja, 12(2), 102-130. https://doi.org/10.1017/CB09781107415324.004

Siboy, A. (2020). Menggali Potensi Sumber Daya Alam Menjadi Kawasan Pariwisata Guna Meningkatkan Pendapatan Desa. Jurnal Pembelajaran Pemberdayaan Masyarakat (JP2M), 1(1), 48-54. https://doi.org/10.33474/jp2m.v1i1.5009

Suprapto, A. (2005). Analisis Penawaran dan Permintaan Wisata Dalam Pengembangan Potensi Pariwisata di Keraton Surakarta Hadiningrat. Universitas Diponegoro.

Suwantoro, G. (2004). Dasar-Dasar Pariwisata (2nd ed.). Yogyakarta: Andi.

Zakaria, F., \& Suprihardjo, R. D. (2014). Konsep Pengembangan Kawasan Desa Wisata di Desa Bandungan Kecamatan Pakong Kabupaten Pamekasan. Teknik Pomits, 3(2), 245-249. https://doi.org/10.12962/j23373539.v3i2.7292 